\title{
UNA PROPOSICIÓN ¿INDECENTE?
}

\section{(COMENTARIOS A LA LEY BALEAR DE REGULACIÓN DE LAS CORRIDAS DE TOROS EN BALEARES)}

Francisco Capacete

El pasado 11 de mayo de 2017, tuvo entrada en el Registro del Parlament de las Islas Baleares una proposición de ley de regulación de las corridas de toros. La iniciativa legislativa ha partido de una coalición de partidos de izquierda que pretende garantizar, como dice su exposición de motivos, "los derechos a la vida y la integridad física y la seguridad de las personas, así como el bienestar de los animales que son objeto de estos espectáculos".

Entre las novedades que plantea esta proposición se hallan las siguientes:

$1^{\text {o. }}$ - Los toros serán devueltos a los corrales tras ser toreados. Se prohíbe dar muerte al toro (artículo 7).

$2^{\circ}$-- Se prohíbe el uso de artilugios que puedan producir heridas y/o la muerte del toro (artículo 8).

3ํ-. Se prohíbe la presencia de caballos durante las corridas de toros (artículo 6).

4ํo- El número máximo de toros que se podrán lidiarse en una corrida será de 3 y su participación no podrá durar más de 10 minutos (artículo 7).

5ํ-. Se prohíbe la entrada a los menores de 18 años (artículo 11).

Esta regulación se ha bautizado por los medios de comunicación como los "toros a la balear", lo cual es una invención mediática, porque nunca ha existido una variante de corrida de toros balear. Las corridas y espectáculos taurinos que se han venido 


\section{dA derecho ANIMAL}

la web center de los animales con derecho

desarrollando en las islas corresponden a la misma modalidad que se conoce en otras regiones de España y en otros países, como Francia, Perú y México, entre otros.

Las formaciones políticas que han redactado y presentado esta proposición de ley, conocidas como el pacto de izquierdas, se han hecho eco de las innumerables peticiones de los colectivos antitaurinos de Baleares. En el mes de febrero de 2016, la entidad Mallorca Sense Sang, presentó en el Parlament 150.000 firmas a favor de la abolición de la tauromaquia en las islas. Efectivamente, la presencia y tradición de la tauromaquia en el archipiélago balear es escasa y se encuentra en un claro declive, solamente sostenido por el apoyo de miembros de la Familia Real Española. La regulación de las corridas de toros que se pretende con esta proposición es, por lo tanto, un intento de casar la voluntad de una parte de los ciudadanos isleños con la legalidad estatal vigente. Si no puede abolirse la tauromaquia, al menos, piensan los parlamentarios de izquierdas, impediremos que sea causa de maltrato animal.

Las corridas de toros, como bien se sabe, no pueden abolirse en España. Existen dos leyes estatales que garantizan la protección y el enriquecimiento de estos festejos. La ley 18/2013, de 12 de noviembre, para la regulación de la tauromaquia como patrimonio cultural y la Ley 10/2015, de 26 de mayo, para la salvaguarda del patrimonio cultural inmaterial, blindan las corridas de toros al considerarlas parte del patrimonio cultural español por integrar la tauromaquia.

Esta proposición supone un intento de diferenciarse de otras comunidades o regiones del Estado español, a través de la restricción de un espectáculo que no cuenta con el fervor de la mayoría de ciudadanos ni forma parte de sus tradiciones culturales más arraigadas. Lo mismo intentó Cataluña en el 2010. El Parlament catalán aprobó mediante Decreto Legislativo 2/2008, de 15 de abril, la Ley 28/2010, de 3 de agosto, de modificación del art. 6 del texto refundido de la Ley de protección de los animales, en el sentido de añadir una letra que prohibía:

“f) Las corridas de toros y los espectáculos con toros que incluyan la muerte del animal y la aplicación de las suertes de la pica, las banderillas y el estoque, así como 


\section{dA derecho ANIMAL}

la web center de los animales con derecho

los espectáculos taurinos de cualquier modalidad que tengan lugar dentro o fuera de las plazas de toros, salvo las fiestas con otros a que se refiere el apartado 2."

Esta ley fue recurrida por inconstitucional ante el Tribunal Constitucional (TC), mediante escrito presentado el 28 de octubre del 2010 y la sentencia se dictó seis años más tarde, dando tiempo al Parlamento estatal de aprobar aquellas dos leyes del 2013 y 2015 que protegen la tauromaquia y que forman parte del argumentario del Tribunal Constitucional como "ius superveniens". Es en base a la vigencia de estas normas y a la invasión de competencias estatales por parte del Parlament catalán que declara inconstitucional el artículo 1 de la Ley 28/2010. Dispone el TC que una comunidad autónoma no puede prohibir la celebración de las corridas de toros, pero sí puede legislar lo que se ha venido en llamar la "policía de espectáculos", es decir, aquellos aspectos que tienen que ver con el desarrollo de la corrida y que tenga que ver con la seguridad de las personas y el orden público. Una comunidad autónoma tiene competencia para legislar sobre la forma, siempre y cuando no limite el contenido esencial de los espectáculos taurinos.

El Pacto de izquierdas ha tomado en consideración la Sentencia del TC y ha realizado un gran esfuerzo dialéctico y literario para evitar usar el verbo "prohibir". En apariencia, sólo regula el desarrollo de la celebración de las corridas de toros que se celebren en las plazas de toros. No dice que se prohíbe dar muerte al bravo, sino que establece que el animal debe regresar vivo a los corrales de la plaza. No dispone que se prohíba la suerte de las banderillas ni asestar punzadas al toro, sino que prohíbe el uso de artilugios con los que pueda herirse o dar muerte a aquel. Formalmente cumple con los requisitos para no invadir las competencias estatales, dado que no prohíbe la celebración de las corridas de toros.

Por otro lado, el TC ha declarado en sus sentencias que proteger la tauromaquia supone, entre otras cosas, protege al toro de lidia. Esta nueva ley lleva al extremo su protección evitándole sufrimientos y muerte. De modo, que se cumple con lo declarado por el Alto Tribunal. 


\section{dA derecho ANIMAL}

la web center de los animales con derecho

Mucho nos tememos que este esfuerzo dialéctico no va a pasar el filtro constitucional. Como muy bien ha aclarado el TC, corresponde al Estado, no solamente proteger la tauromaquia -incluyendo las corridas de toros que son su elemento esencial-, sino también enriquecerla. La regulación de las corridas de toros de la proposición de ley que comentamos empobrece la corrida de toros, la limita de tal manera que su resultante será apenas un triste remedo de las corridas actuales.

Tras el intenso debate parlamentario, el 24 de julio de 2017, la cámara de diputados balear aprobó por mayoría la Ley de regulación de espectáculos taurinos que supone, sin duda, un avance en la protección de los animales y abre una nueva brecha en el muro de las intocables tradiciones que incluyen sufrimiento de los animales. Ahora toca esperar la reacción de los grupos parlamentarios que se han opuesto al texto de la ley, así como al Gobierno del Estado que ya han anunciado que van a recurrir la norma ante el Tribunal Constitucional.

Algunos especialistas, entre los que me encuentro, opinamos que la iniciativa balear que se ha convertido en ley está condenada al fracaso. Así se lo hemos expresado a los promotores parlamentarios. Pero parece ser que, además de regular los espectáculos taurinos inspirándose en el bienestar animal y la legislación europea, esta ley autonómica también constituye una proposición indecente dirigida al TC. ¿Se pronunciará sobre si la muerte del toro es esencial en la lidia y representa una de las características fundamentales de la tauromaquia? La posible futura sentencia, ¿señalará solamente el ámbito competencial sin entrar en el logos del sufrimiento animal? 